\title{
PEMBUATAN RESISTANT STARCH PATI BERAS DENGAN METODE ENZIMATIS DAN FISIK
}

\author{
Tanwirul Millati ${ }^{1}$, Nurhayati ${ }^{*}$ \\ ${ }^{1}$ Program studi Teknologi Industri pertanian, Univertas Lambung Mangkurat, Indonesia \\ ${ }^{2}$ Program studi Teknologi hasil pertanian, Universitas Muhammadiyah Mataram, Indonesia \\ *Co-author: nurhayati.faperta.ummat@gmail.com
}

\section{Paper Information}

History:

Received : 06-08- 2020

Accepted: 30-10-2020

\section{Key words:}

Resistant Starch

Rice starch

Enzymatic treatment

Physical treatment

\begin{abstract}
Abstrak: Beras merupakan makanan pokok dan sumber karbohidrat bagi sebagian besar penduduk dunia dan Indonesia, namun sebagian besar beras cenderung memiliki indeks glikemik (IG) tinggi. Sebuah produk dengan IG rendah adalah lebih baik, tidak hanya bagi penderita diabetes, tetapi juga bagi orang sehat. Resistant starch (RS) berfungsi sebagai bahan makanan baru yang memiliki indeks glikemik rendah. RS merupakan bagian pati atau produk pati yang resisten terhadap pencernaan ketika melalui gastrointestinal tract. RS mempunyai efek fisiologis yang sama dengan serat pangan, dapat mempengaruhi berat badan dan keseimbangan energy, dapat meningkatkan ekskresi lipid sehingga dapat mengurangi asupan kalori dan menurunkan tingkat lipid serum, kandungan kalorinya nol sehingga bisa digunakan sebagai food additive rendah kalori yang dapat mengendalikan berat badan secara efektif. RS dapat dibuat melalui modifikasi pati dengan perlakuan fisik (perlakuan panas), perlakuan kimia, perlakuan enzimatis dan kombinasi panas dan enzimatis. Faktor yang mempengaruhi pembentukan RS diantaranya sifat pati, interaksi pati dengan komponen lain, kondisi prosesing, proses panas, perlakuan lain dan kondisi penyimpanan. Oleh karena itu, modifikasi pati beras yang banyak mengandung RS perlu untuk diketahui. Hidrolisis pati beras dengan enzim ganda $\alpha$-amilase dan pululanase (DMT) dapat meningkatkan kadar RS tertinggi (51,0\%) karena meningkatnya derajat kristalniatas pati. RS yang tinggi mengakibatkan peningkatan suhu gelatinisasi, $\Delta \mathrm{H}$ dan suhu fase transisi dan penurunan kecepatan hidrolisis pati dan kehilangan berat.
\end{abstract}

Abstract: Rice is the leading food and a carbohydrate source for most of the world's and Indonesia population, but most rice tends to have a high glycemic index (IG). A product with a low IG is better, not only for people with diabetes but also for healthy people. Resistant starch (RS) functions as a new food ingredient that has a low glycemic index. RS is a part of starch or starch products resistant to digestion when through a gastrointestinal tract. RS has the same physiological effects as dietary fiber, can affect body weight and energy balance, increase lipid excretion to reduce calorie intake and reduce serum lipid levels, zero caloric content so that it can be used as a low-calorie food additive that can control body weight effectively. RS can be made through starch modification by physical treatment (heat treatment), chemical treatment, enzymatic treatment, and a combination of heat and enzymatic. Factors that influence RS's formation include starch properties, starch interactions with other components, processing conditions, heat processes, other treatments, and storage conditions. Therefore, the rice starch modification that contains a lot of RS needs to be known. Rice starch Hydrolysis with the dual enzyme $\alpha$-amylase and pullulanase (DMT) can increase the highest RS level (51.0\%) due to the increased degree of starch crystallinity. High RS results in an increase in gelatinization temperature, $\Delta \mathrm{H}$ and phase transition temperatures, and a decrease in the speed of starch hydrolysis and weight loss. 


\section{A. LATAR BELAKANG}

Peningkatan permintaan konsumen terhadap produk makanan berkualitas tinggi telah menyebabkan pertumbuhan dalam penggunaan bahan-bahan dan teknologi baru. Beberapa faktor yang mempengaruhi perubahan permintaan konsumen adalah : masalah kesehatan (kolesterol, kanker, obesitas), perubahan karakteristik demografi (etnis, populasi yang menua, dll), kebutuhan untuk kenyamanan, perubahan dalam sistem distribusi dan harga (Fuentes-Zaragoza, M. J. RiquelmeNavarrete, et al., 2010).

Semakin besar kesadaran konsumen tentang hubungan antara makanan bergizi dan kesehatan telah menjadi salah satu alasan untuk peningkatan popularitas makanan dengan sifat gizi yang baik ('Los alimentos del bienestar la alimentación del siglo XXI - IAlimentos', no date; Sanz, Salvador and Fiszman, 2008) dalam (FuentesZaragoza, M.J. Riquelme-Navarrete, et al., 2010). Hal tersebut sebenarnya dapat diperoleh dari pangan fungsional, yaitu pangan yang dapat memberikan nutrisi dasar juga menyediakan keuntungan fisiologis dan atau dapat mengurangi resiko penyakit kronis. Pangan fungsional yang sudah ada dalam makanan atau yang ditambahkan dari luar dapat memberikan efek kesehatan yang positif atau menghilangkan komponen negatif. Salah satu pangan fungsional yang sekarang banyak diteliti adalah resistant starch (Mikulíková, Masár and Kraic, 2008). Menurut (Zhou et al., 2014) resistant starch (RS) berfungsi sebagai bahan makanan baru yang memiliki indeks glikemik rendah. RS disebut sebagai pati anti pencernaan, yaitu sebagian kecil dari pati yang tidak dapat dicerna dalam usus kecil dan difermentasi dalam usus besar untuk menghasilkan asam lemak rantai pendek dan produk lainnya. RS ditandai dengan struktur molekul yang lebih kecil dengan panjang 20-25 residu glukosa (polisakarida linear yang dihubungkan oleh ikatan hidrogen).

Beras merupakan makanan pokok dan sumber karbohidrat bagi sebagian besar penduduk dunia dan Indonesia. Sejumlah produk makanaan tradisional banyak yang dibuat dengan menggunakan bahan baku beras. Namun, sebagian besar beras cenderung memiliki indeks glikemik (IG) tinggi. Sebuah produk dengan IG rendah adalah lebih baik, tidak hanya bagi penderita diabetes, tetapi juga bagi orang sehat. Oleh karena itu modifikasi pati beras yang banyak mengandung RS mempunyai nilai kesehatan yang nyata bagi masyarakat (Sha et al., 2012).

\section{B. PEMBAHASAN}

\section{RESISTANT STARCH (RS)}

Pati adalah polisakarida yang disusun oleh unit-unit D-glukosa merupakan homoglukan atau glukopiranosa yang terdiri atas dua biomakromolekul utama, yaitu amilosa dan amilopektin. Amilosa merupakan glukosa rantai lurus dengan ikatan $\alpha-(1-4)$ dengan berat molekul 105-106 dan derajat polimerisasi sampai 600. Sedang amilopektin merupakan polimer yang banyak mempunyai rantai cabang dengan berat molekul tinggi 107-109, dengan ikatan $\alpha-(1-4)$ (sekitar 95\%) dan ikatan rantai cabang $\alpha-(1-6)$ (sekitar $5 \%$ ), dengan titik percabangan terjadi setiap 22-70 unit glukosa (Xie et al., 2013). Struktur pati, amilosa dan amilopektin dapat dilihat pada Gambar 1.

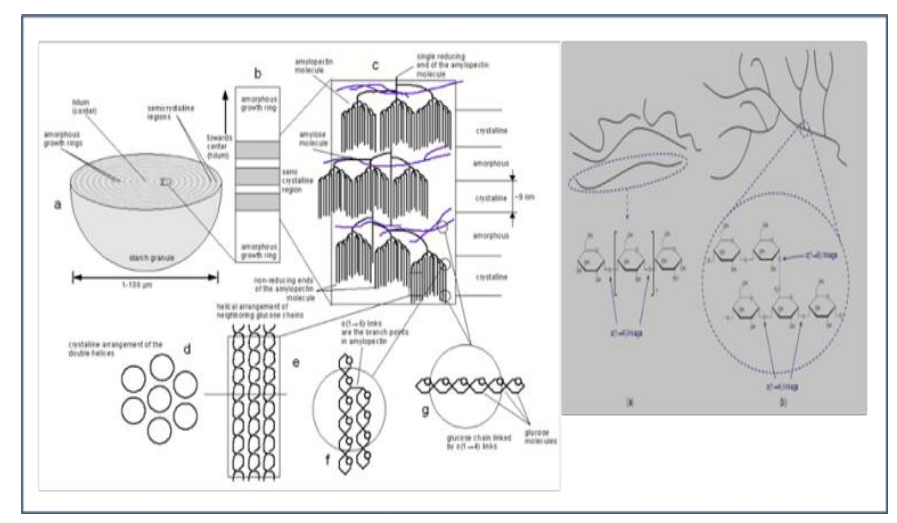

Gambar 1. Ilustrasi struktur granula pati (Waigh et al., 1997; Xie et al., 2013)

Ada dua struktur kristalin yang telah diidentifikasi (tipe A dan tipe B) yang mengandung proporsi amilopektin yang berbeda. Pati tipe A ditemukan pada bijia-bijian (serealia), sedang pati tipe B pada umbiumbian dan pati dengan kadar amilosa tinggi. Tipe ketiga yang disebut tipe $\mathrm{C}$ merupakan campuran kedua tipe A dan B ditemukan dalam kacang-kacangan (legume). Pada umumnya, pati dicerna (hidrolisis) oleh enzim a-amilase, glucoamilase dan sucrase-isomaltase di dalam usus halus menghasilkan glukosa yang kemudian diserap. Namun tidak semua pati makanan dicerna dan diserap dalam usus halus (Nugent, 2005; Ratnayake and Jackson, 2008).

Resistant starch (RS) merupakan bagian pati atau produk pati yang resisten terhadap pencernaan ketika melalui gastrointestinal tract. RS adalah fraksi pati yang tidak dihidrolisis menjadi D- glukosa di usus halus dalam waktu 120 menit setelah dikonsumsi, tetapi difermentasi dalam usus besar (kolon). Banyak penelitian telah menunjukkan bahwa RS adalah molekul linear dari 1,4 $\alpha$ D-glukan yang berasal dari fraksi amilosa yang mengalami retrogradasi, dan memiliki berat molekul yang relatif rendah $\left(1,2 \times 10^{5} \mathrm{Da}\right)$. Karena sifatnya yang tahan terhadap enzim mamalia, RS dapat diklasifikasikan sebagai komponen serat berdasar definisi serat pangan yang diberikan oleh the American Association of Ceral Chemists tahun 2000 dan the National Academic of Science tahun 2002 (Fuentes-Zaragoza, M.J. RiquelmeNavarrete, et al., 2010).

RS adalah molekul kecil yang terdiri atas 20-25 residu glukosa yang dihubungkan dengan ikatan hydrogen. RS mempunyai efek fisiologis yang sama dengan serat pangan, dapat mempengaruhi berat badan dan keseimbangan energy, dapat meningkatkan ekskresi lipid sehingga dapat mengurangi asupan kalori dan menurunkan tingkat lipid serum, kandungan kalorinya 
nol sehingga bisa digunakan sebagai food additive rendah kalori yang dapat mengendalikan berat badan secara efektif (Zhou et al., 2014).

Beberapa pendapat menyatakan bahwa RS tidak dapat dicerna karena empat alasan, yaitu :

1. Struktur molekul pati sangat kompak sehingga membatasi aksesibilitas berbagai enzim-enzim pencernaan, seperti dalam biji-bijian atau umbiumbian.

2. Struktur molekular granula pati mencegah enzim pencernaan untuk menghidrolis

pati, misalnya kentang mentah, pisang mentah dan pati jagung tinggi amilosa.

3. Granula pati mengalami gelatinisasi karena pemanasan dengan sejumlah air. yang membuat molekul mudah diakses oleh enzim pencernaan. Namun, jika gel pati kemudian didinginkan, mereka membentuk kristal pati yang resisten terhadap enzim pencernaan (bentukpati teretrogradasi)

4. Pati yang telah dimodifikasi secara kimia dengan eterisasi, esterisasi atau ikatan silang sehingga tidak bisa dipecah oleh enzim pencernaan.

Menurut (Fuentes - Zaragoza et al., 2011) RS dapat diklasifikasikan menjadi lima (5) tipe, yaitu RS1, RS2, $\mathrm{RS}_{3}, \mathrm{RS} 4$ dan $\mathrm{RS}_{5}$. RS1 adalah pati yang secara fisik terlindung oleh dinding sel dan matriks sehingga tidak bisa dicerna, RS2 adalah granula pati alami yang tidak tergelatinisasi dan dihidrolisis dengan lambat oleh amylase, RS3 adalah pati retrogradasi atau pembentukan kristalin setelah pemasakan, RS4 adalah pati yang dimodifikasi secara kimia atau pati re-polimerisasi dan $\mathrm{RS}_{5}$ adalah pati yang amilosanya membentuk kompleks amilosa- lipida. Pada Gambar 2 dapat dilihat gambar skematik RS1-RS5, sedang deskripsi, perbedaan resistensi RS1-RS4 terhadap proses pencernaan di usus halus dan sumber dari masing-masing tipe RS dapat dilihat pada Tabel 1.

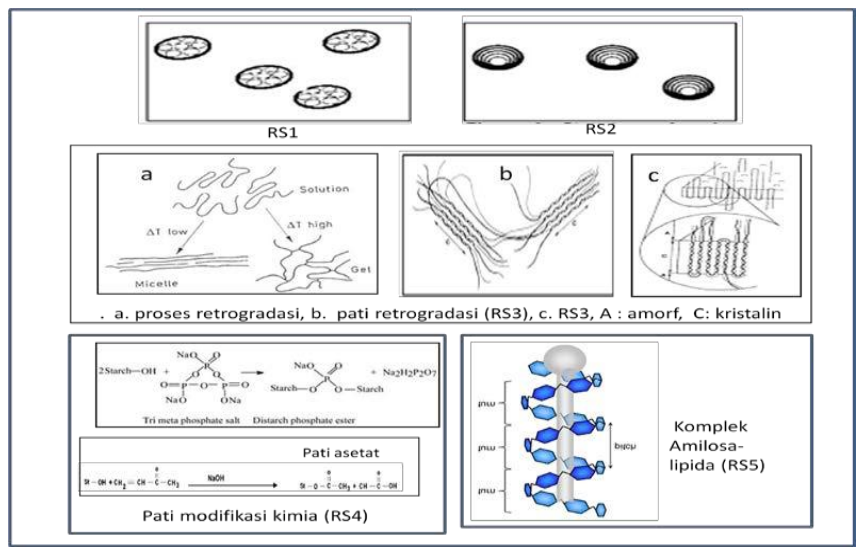

Gambar 2. Skematik RS1- RS5 (Sumber : (Sajilata, Singhal and Kulkarni, 2006; Putseys, Lamberts and Delcour, 2010)

Nilai cerna RS tergantung pada kategori dan sumber RS yang dikonsumsi. Dari total $\mathrm{RS}_{3}$ yang ada dalam jagung terdegradasi oleh fermentasi bakteri di usus besar sekitar $84 \%$, sedang pada gandum sekitar $65 \%$. Untuk tipe RS2 dalam kentang mentah yang terdegradasi oleh fermentasi bakteri di usus besar sebesar 89 \% dan pada pisang hijau $96 \%$. Degradasi RS juga dipengaruhi oleh berbagai kondisi pengolahan makanan dimana RS dihasilkan. Daya cerna RS juga ditemukan bervariasi per individu. Variabilitas ini kemungkinan disebabkan perbedaan tanggapan individu terhadap aktivitas enzim (Sharma and Yadav, 2008).

Tabel 1.

Tipe Pati Resisten, Resistensi Terhadap Proses Pencernaan Dan Sumbernya

\begin{tabular}{|c|c|c|c|c|}
\hline $\begin{array}{l}\text { Tipe } \\
\text { RS }\end{array}$ & Deskripsi & $\begin{array}{l}\text { Kecernaan } \\
\text { di usus } \\
\text { halus }\end{array}$ & $\begin{array}{l}\text { Resistensi } \\
\text { direduksi } \\
\text { oleh }\end{array}$ & $\begin{array}{l}\text { Sumber } \\
\text { pangan }\end{array}$ \\
\hline $\mathrm{RS} 1$ & $\begin{array}{l}\text { Secara fisik } \\
\text { tidak dicerna } \\
\text { karena } \\
\text { terperangkap } \\
\text { di dalam } \\
\text { matriks yang } \\
\text { tidak bisa } \\
\text { dicerna }\end{array}$ & $\begin{array}{l}\text { Kecepatan } \\
\text { lambat, } \\
\text { dicerna } \\
\text { parsial; } \\
\text { dicerna } \\
\text { sempurna } \\
\text { jika digiling } \\
\text { secara } \\
\text { sempurna }\end{array}$ & $\begin{array}{l}\text { Penggiling } \\
\text { an dan } \\
\text { pengunya } \\
\text { han }\end{array}$ & $\begin{array}{l}\text { Biji dan } \\
\text { sereal utuh } \\
\text { atau yang } \\
\text { digiling } \\
\text { parsial, } \\
\text { pasta }\end{array}$ \\
\hline RS2 & $\begin{array}{l}\text { Granula } \\
\text { yang resisten } \\
\text { dalam } \\
\text { bentuk tidak } \\
\text { digelatinisasi } \\
\text {, memiliki } \\
\text { kristalinitas } \\
\text { tipe B, } \\
\text { terhidrolisis } \\
\text { secara } \\
\text { lambat oleh } \\
\text { a-amilase }\end{array}$ & $\begin{array}{l}\text { Kecepatan } \\
\text { sangat } \\
\text { lambat, } \\
\text { dicerna } \\
\text { dalam } \\
\text { jumlah } \\
\text { sangat } \\
\text { sedikit, } \\
\text { dicerna } \\
\text { sempurna } \\
\text { jika pati } \\
\text { dimasak }\end{array}$ & $\begin{array}{l}\text { Pemasaka } \\
\mathrm{n} \text { dan } \\
\text { pengolaha } \\
\mathrm{n} \text { pangan }\end{array}$ & $\begin{array}{l}\text { Kentang } \\
\text { mentah, } \\
\text { pisang } \\
\text { mengkal, } \\
\text { beberapa } \\
\text { kacang- } \\
\text { kacangan, } \\
\text { pati amilosa } \\
\text { tinggi }\end{array}$ \\
\hline RS3 & $\begin{array}{l}\text { Pati } \\
\text { retrogradasi, } \\
\text { terbentuk } \\
\text { ketika } \\
\text { pangan yang } \\
\text { mengandung } \\
\text { pati dimasak } \\
\text { dan } \\
\text { didinginkan }\end{array}$ & $\begin{array}{l}\text { Kecepatan } \\
\text { lambat, } \\
\text { dicerna } \\
\text { parsial, } \\
\text { ketercernaa } \\
\text { n meningkat } \\
\text { jika } \\
\text { dipanaskan } \\
\text { ulang }\end{array}$ & $\begin{array}{l}\text { Kondisi } \\
\text { proses } \\
\text { pengolaha } \\
\text { n }\end{array}$ & $\begin{array}{l}\text { Kentang } \\
\text { yang } \\
\text { dimasak dan } \\
\text { didinginkan, } \\
\text { roti, flake } \\
\text { jagung, } \\
\text { produk } \\
\text { pangan } \\
\text { dengan } \\
\text { moist heat } \\
\text { treatment } \\
\text { yang } \\
\text { panjang dan } \\
\text { berulang }\end{array}$ \\
\hline $\mathrm{RS}_{4}$ & $\begin{array}{l}\text { Pati resisten } \\
\text { hasil } \\
\text { modifikasi } \\
\text { kimia }\end{array}$ & $\begin{array}{l}\text { Tahan } \\
\text { terhadap } \\
\text { hidrolisis }\end{array}$ & $\begin{array}{l}\text { Kurang } \\
\text { rentan } \\
\text { terhadap } \\
\text { kecernaan } \\
\text { in vitro }\end{array}$ & $\begin{array}{l}\text { Dalam } \\
\text { minuman } \\
\text { atau } \\
\text { makanan } \\
\text { yang telah } \\
\text { ditambahka } \\
\text { n pati } \\
\text { resisten tipe } \\
4\end{array}$ \\
\hline
\end{tabular}

Sumber : (Fuentes-Zaragoza, M.J. Riquelme-Navarrete, et al., 2010)

\section{a. Sifat Fungsional RS}

RS memiliki ukuran partikel kecil, berwarna putih, flavor hambar, water holding capacity (WHC) rendah, mempunyai sifat fisikokimia yang dikehendaki seperti peningkatan pengembangan dan viskositas, pembentukan gel dan water binding capacity (WBC) sehingga dapat digunakan dalam bermacam-macam makanan. Sifat-sifat ini memungkinkan penggunaan 
RS untuk menggantikan tepung satu banding satu tanpa mempengaruhi penanganan atau rheologi adonan. RS tidak hanya memperkaya serat tetapi juga memberi karakteristik khusus yang tidak diberikan makanan tinggi serat. RS memiliki suhu gelatinisasi tinggi, ekstrusi yang baik dan pembentuk film yang berkualitas, dan kapasitas pengikatan air yang lebih rendah dari pada produk serat tradisional. Dapat digunakan meningkatkan tekstur, penampilan , dan kualitas organoleptik yang lebih baik dibandingkan dengan produk-serat tinggi tradisional, menurunkan nilai kalor makanan dan sebagai pencahar dan terapi rehidrasi oral (Sajilata, Singhal and Kulkarni, 2006). Sifat-sifat fungsional dari RS2 dan RS3 dapat dilihat pada Tabel 2.

Tabel 2.

\section{Sifat fungsional dan keuntungan} komersial RS2/ RS3

\begin{tabular}{ll}
\hline No & Sifat fungsional dan Keuntungan Komersial \\
\hline 1 & Sumber alami \\
2 & Flavor hambar \\
3 & Warna putih \\
4 & Suhu gelatinisasi tinggi \\
5 & Ukuran partikel halus (tidak terlalu mempengaruhi \\
& tekstur) \\
6 & Berguna sebagai pencahar massal dan produk untuk \\
& terapi rehidrasi oral \\
7 & Memungkinkan untuk pengembangan produk-serat \\
& tinggi dengan penampilan dan rasa dimulut lebih baik \\
& (kualitas organoleptik yang lebih baik) dibandingkan \\
8 & dengan produk serat tinggi tradisional \\
9 & Meningkatan kerenyahan \\
10 & Functionalkan rasa kongingredients \\
11 & Nilai kalori makanan rendah \\
12 & Sifat air yang lebih rendah dari pada produk serat \\
13 & Ekstrusi yang baik dan kualitas pembentuk film \\
\hline
\end{tabular}

Sumber: (Fuentes-Zaragoza, M.J. Riquelme-Navarrete, et al., 2010)

\section{b. Efek Fisiologis RS Yang Menguntungkan}

RS telah banyak mendapat perhatian karena dua hal, yaitu manfaat bagi kesehatan dan sifat fungsional (Sajilata, Singhal and Kulkarni, 2006). RS adalah salah satu sumber karbohidrat yang tidak dapat dicerna dalam makanan yang paling berlimpah dan bisa sama pentingnya dengan NSP (Non Starch Polysaccaride) dalam mendukung kesehatan usus besar, mencegah penyakit radang usus (IBDinflammatory bowel disease), kanker kolorektal (CRC-colorectal cancer) (Topping, Fukushima and Bird, 2003; Nugent, 2005).

Sejumlah efek fisiologis menguntungkan yang berasal dari RS dan telah terbukti bermanfaat bagi kesehatan dapat dilihat pada Tabel 3. Sifat fisiologis RS dapat sangat bervariasi tergantung pada desain studi, perbedaan sumber RS, jenis dan dosis RS dikonsumsi. Ada kemungkinan bahwa pengolahan modern dan praktek konsumsi pangan telah menyebabkan RS yang dikonsumsi rendah, yang dapat berkontribusi terhadap kenaikan penyakit usus besar yang serius di negara-negara makmur. Hal ini membuka kesempatan untuk pengembangan kultivar baru sereal dan bahan berbasis pati untuk produk-produk makanan yang dapat meningkatkan kesehatan masyarakat (Topping, Fukushima and Bird, 2003; Sharma and Yadav, 2008).

Tabel 3.

Efek fisiologis RS

\begin{tabular}{ll}
\hline Protective effect & $\begin{array}{l}\text { Potential physiological } \\
\text { effects }\end{array}$ \\
\hline Diabetes & $\begin{array}{l}\text { Control of glycemic, } \\
\text { insulinemic responses } \\
\text { Improved bowel health }\end{array}$ \\
$\begin{array}{l}\text { Colorectar cancer, ulcerative } \\
\text { colitis, inflammatory bowel } \\
\text { disease, diverticulitis and } \\
\text { constipation }\end{array}$ & \\
$\begin{array}{l}\text { Cardiovascular disease, lipid } \\
\text { metabolism syndrome, } \\
\text { cholesterol and triglycerides } \\
\text { Colonic health }\end{array}$ & $\begin{array}{l}\text { Improved blood lipid } \\
\text { profile }\end{array}$ \\
$\begin{array}{l}\text { Obesity } \\
\text { Prebiotic, culture } \\
\text { protagonist }\end{array}$ \\
$\begin{array}{l}\text { Increased satiety, reduced } \\
\text { calcium absorption }\end{array}$ & $\begin{array}{l}\text { Increased micronutrient } \\
\text { absorption }\end{array}$ \\
\hline
\end{tabular}

Sumber : (Fuentes-Zaragoza, M.J. Riquelme-Navarrete, et al., 2010)

\section{c. Faktor-Faktor Yang Mempengaruhi Pembentukan RS (i) Sifat-sifat pati Kristalinitas.}

Salah satu yang menyebabkan resisten terhadap enzim adalah kristalinitas tipe B pada pati jagung alami dan pati yang berada dalam struktur sel dan jaringan tanaman. Beberapa perlakuan yang dapat menghilangkan kristalinitas pati adalah gelatinisasi atau penggilingan dapat meningkankan kecernaan terhadap enzim dan meurunkan kadar RS. Rekristalisasi atau modifikasi kimia cenderung meningkatkan RS. Disamping strukrur seluler, kecernaan pati dalam usus halus dipengaruhi bentuk fisik partikel pati (Sajilata, Singhal and Kulkarni, 2006). Struktur granula.

Kecernaan granula pati terhadap amilase bervariasi dan hal ini mempengaruhi pembentukan RS. Pati kentang dan pati jagung tinggi amilosa sangat resisten terhadap enzim secara invitro dan secara invivo tidak diserap sempurna, sedang sebagian pati sereal lambat dicerna tetapi secara invivo dicerna dan diserap sempurna. Rasio luas permukaan dengan volume berperan penting, luas permukaan granula menentukan penyerapan komponen lain yang secara efektif menghalangi enzim (Holm J, Asp NG, Bjorck I, no date; Ring et al., 1988) dalam (Sajilata, Singhal and Kulkarni, 2006). 


\section{Rasio amilosa-amilopektin.}

Kadar amilosa yang tinggi tingkat kecernaan pati rendah, karena korelasi positif antara kadar amilosa dan pembentukan RS (Berry, 1986; Sievert and Pomeranz, 1989) dalam (Sajilata, Singhal and Kulkarni, 2006).

\section{Retrogradasi amilosa.}

Pati yang dipanaskan sampai terjadi gelatinisasi menyebabkan pati sangat mudah dicerna, apabila pati yang tergelainisasi ini didinginkan atau dikeringkan rekristalisasi (retrogradasi) terjadi. Retrogradasi terjadi sangat cepat pada bagian amilosa yang strukturnya linier dengan pembentukan ikatan silang berupa ikatan hidrogen, sedang pada bagian amilopektin retrogradasi terjadi setelah beberapa hari. Kecepatan dan banyaknya pati yang mengalami retrogradasi setelah gelatinisasi sangat tergantung jumlah amilosa (Ring et al., 1988) dalam (Sajilata, Singhal and Kulkarni, 2006).

\section{Panjang rantai amilosa.}

Derajat Polimerisasi (DP) RS bervariasi antara 19-26 dan tergantung dari panjang rantai amilosa (DP 40610). RS bisa dibentuk dengan agregasi heliks amilosa dan struktur kristalin tipe B khususnya pada bagian rantai yang terdiri atas 24 unit glukosa.

\section{Linieritas amilopektin.}

Linierisasi amilopektin terjadi selama proses pemangggangan suhu rendah karena memperpanjang aktivitas amilase intrinsik dalam adonan dan ini sangat terlihat dengan adanya asam organik, dalam produk roti biasanya ditambah asam laktat. Peningkatan RS juga terjadi selama pemanasan basah (wet-autoclaving)(Berry, 1986; Liljeberg, Åkerberg and Björck, 1996) dalam (Sajilata, Singhal and Kulkarni, 2006).

\section{(ii) Panas dan kadar air}

Kadar air merupakan faktor penting yang mempengaruhi pembentukan RS. Perlakuan panas/ kelembaban berulang-ulang terkait dengan penurunan hidrolisis oleh $\alpha$-amilase dan peningkatan pembentukan RS. Hasil RS yang maksimum diperoleh dari perlakuan dengan rasio pati : air $=1$ : 3,5 (w/w) dan perlakuan panas pada kadar air 18\% meningkatkan derajat ksistalinitas pada pati normal dan waxy dan mengurangi kecernaan terhadap enzim. Tetapi pada kadar air 27\%, pati mengalami degradasi dan menyebabkan pati lebih mudah diserang enzim. Pada suhu yang lebih tinggi dan air yang lebih rendah menghasilkan konfigurasi tipe A, sedang pada suhu rendah dan kadar air tinggi menghasilkan konfigurasi tipe B (Wu and Sarko, 1978) dalam (Sajilata, Singhal and Kulkarni, 2006)

\section{(iii) Interaksi antara pati dengan komponen}

Interaksi antara pati dengan komponen lain yang berbeda diketahui mempengaruhi pembentukan RS (Sajilata, Singhal and Kulkarni, 2006).

Protein. Interaksi pati-protein dipercaya dapat menurunkan kadar RS, yang telah diamati pada pati kentang dan albumin pada saat dipanaskan dan didinginkan pada suhu $-20^{\circ} \mathrm{C}$.

Serat pangan. Serat pangan yang tidak larut seperti selulosa dan lignin diketahui mempunyai pengaruh kecil terhadap RS dibandingkan dengan senyawa/ unsur lain seperti potasium, kalsium dan katekin.

Inhibitor enzim. Polifenol, asam fitat dan lektin pada leguminosa dilaporkan menghambat hidrolisis pati secara in vitro dan indeks glikemik yang lebih rendah. Asam tanat menghambat aktivitas amilase dan maltase usus halus. Masih ada informasi yang kontradiksi dalam literatur pada aspek ini.

Ion. Hasil RS pada gel pati kentang turun dengan adanya ion kalsium dan potasium dibandngkan dengan tanpa penambahan unsur tersebut, yang dikarenakan pencegahan pembentukan ikatan hidrogen antara rantai amilosa dan amilopektin yang disebabkan oleh penyerapan ion-ion tersebut.

Gula. Penambahan gula yang dapat larut seperti glukosa, maltosa, sukrosa dan ribosa menurunkan derajat kristalisasi sehingga menurunkan hasil RS. Mekanisme retrogradasi dihambat karena interaksi antara molekul gula dan molekul pati yang mengubah matriks pati tergelatinisasi.

Lipid, emulsifier. Amilosa dengan lipid dapat membentuk komplek amilosa-lipida. Komplek amilosa-lipida merupakan enzyme-degradable dan peningkatan komplek amilosa akan mengurangi hasil RS. Rekristalisasi amilosa dalam pembentukan RS bersaing dengan pembentukan komplek amilosa. Memang ada perbedaan pendapat diantara peneliti, beberapa peneliti meyakini bahwa komplek amilosalipida menurunkan pembentukan RS, tapi peneliti lain berpendapat bahwa komplek amilosa-lipida itu sendiri adalah salah bentuk RS. Pengaruh lipid endogen dalam pembentuk RS dari pati gandum menunjukkan defatting menurunkan kadar RS, tetapi ketika lipid ditambahkan pada gandum defatted atau pati amylomaize VII terjadi penurunan RS.

\section{(iv) Kondisi prosesing}

Teknik prosesing dapat mempengaruhi proses gelatinisasi dan retrogradasi, yang akhirnya mempengaruhi pembentukan RS. Fakta ini sangat penting untuk industri makanan, karena hal ini memungkinkan meningkatkan kadar RS pada saat makanan atau bahan makanan diproses. Pemanggangan, produksi pasta, ekstrusi, pemanasan dan seterusnya diketahui mempengaruhi hasil RS dalam makanan (Sajilata, Singhal and Kulkarni, 2006). 


\section{(v) Proses Panas}

Pengukusan. Pengukusan membantu dalam produksi RS. Pati yang diisolasi dari legum yang dikukus kaya akan RS (19\% sampai 31\%) dan tidak ditemukan pada kacang mentah. Hal yang sama terjadi pada kacang yang dikukus secara konvesional dan pada tekanan tinggi, kadar RS meningkat 3 sampai 5 kali lebih tinggi dari pada kacang mentah, hal ini menunjukkan bahwa retrogradasi yang bertanggung jawa terhadap penurunan nilai kecernaan. Autoclaving. Pemanasan menghasilkan peningkatan RS. Pemanasan pati jagung mengandung RS 9\% dibandingkan dengan jagung yang tidak dimasak kadarnya kurang dari $1 \%$.

Parboiling. Parboiling dapat meningkatkan produksi RS. Dalam penelitian lima varietas beras dengan kadar amilosa yang berbeda, secara in vitro dan in vivo kadar RS rendah dan berkorelasi positif dengan kadar amilosa. Kadar RS yang lebih tinggi ditemukan pada nasi dan nasi parboiled dari pada dalam beras. Kadar RS yang lebih tinggi dilaporkan dalam beras parboiled dari pada beras putih, peningkatan juga terjadi karena pendinginan dan pembekuan.

Pemanggangan. Pemanggangan meningkatkan kadar RS. Hasil penelitian menunjukkan bahwa kadar RS pada adonan roti paling rendah dan setelah dipanggang kadar paling tinggi terjadi pada bagian dalam roti dibandingkan pada kulit roti.

Ekstrusi. Kadar RS3 dari tepung barley alami, pada umumnya berkurang dengan ekstrusi, tetapi tidak signifikan. Penyimpanan sampel tepung ekstrudad pada $4^{\circ} \mathrm{C}$ selama 24 jam sebelum pengeringan terjadi sedikit peningkatan konten RS3. Pati jagung dengan dan tanpa guar [10\% (b/b)] dan 2\% (b/b) monogliserida ester asam tartarat diacetyl, sodium stearoil-2- laktilat atau asam sitrat, masing-masing diekstrusi dalam ekstruder twin-screw pada kelembaban $18 \%, 150^{\circ} \mathrm{C}$, dan kecepatan putar $180 \mathrm{rpm}$. Pembentukan RS pada pati jagung yang diekstrusi sangat dipengaruhi oleh penambahan gum dan aditif makanan yang berbeda. Pola Difraksi sinar-X memberikan pola difraksi V, hal ini menunjukkan efek ekstrusi dan adanya kompleks amilosa-lipid (Wu and Sarko, 1978; Faraj, Vasanthan and Hoover, 2004) dalam (Sajilata, Singhal and Kulkarni, 2006).

Pirokonversi. Piroconversi pati meningkatkan kadar RS. Pati Lima bean (Phaseolus lunatus) yang dimodifikasi menggunakan piroconversi, dengan perlakuan $\mathrm{HCl}$ dengan rasio pati $\mathrm{HCl}=160: 1$, pada suhu $90^{\circ} \mathrm{C}$ selama 1 jam, menghasilkan pati yang mengandung 49,5\% pati tidak tercerna. Pati pirodekstrinisasi menurunkan jumlah pati tersedia bagi enzim melalui pembentukan ikatan glikosidik yang tidak dicerna oleh amilase dan maltooligosakaridase di usus kecil manusia (Sajilata, Singhal and Kulkarni, 2006).

Irradiasi microwave. Iradiasi Microwave meningkatkan kecernaan pati umbi, disertai dengan perubahan struktur dan fisikokimia. Kadar RS buncis mentah dan kacang-kacangan menurun dari 32,5\% (dari total pati) masing-masing menjadi sekitar 10\% setelah dimasak, dan tingkat kecernaan pati meningkat dari 35,6\% dan 27,5\% menjadi sekitar 80\%. Studi tentang efek perlakuan yang berbeda panas menunjukkan peningkatan pati dicerna dan penurunan RS setelah perlakuan panas (Sajilata, Singhal and Kulkarni, 2006).

\section{(vi) Perlakuan lain-lain}

Penggilingan. Kacang-kacangan, di mana struktur sel setelah dimasak (seperti roti dengan biji utuh) ; tepung kacang dengan sel utuh; makanan yang mengandung partikel besar seperti roti dengan biji utuh secara fisik sulit diakses oleh amilase, sehingga meningkatkan kadar RS. (Adamu, 2001) dalam (Sajilata, Singhal and Kulkarni, 2006) menemukan bukti bahwa $20 \%$ pati tidak terserap (malabsorpsi) dari diet yang mengandung tepung kacang dengan sel utuh. Sekitar setengah dari pati yang tidak terserap tersebut adalah amilosa teretrogradasi.

Perkecambahan. Perkecambahan terbukti menurunkan kandungan RS dalam bengal gram, field bean, cow pea, dan green gram (Schweizer et al., 1990) dalam (Sajilata, Singhal and Kulkarni, 2006). Fermentasi. Fermentasi mengurangi kadar RS Tepung sorghum dicampur dengan air dan difermentasi dengan starter pada suhu $37^{\circ} \mathrm{C}$ selama 36 jam menunjukkan peningkatan keccernaan pati in vitro dan menurunkan kadar $\mathrm{RS}$ dan jumlah pati. Pembentukan RS juga telah terbukti menurun dalam produk fermentasi idlis dan dhoklas (Kavita et al., 1998; Abd-Elmoneim-O-Elkhalifa, Schiffler and Bernhard, 2004) dalam (Sajilata, Singhal and Kulkarni, 2006).

\section{(vii) Kondisi Penyimpanan}

Umumnya, RS meningkat pada penyimpanan, terutama penyimpanan pada suhu rendah. Roti jagung utuh dan jagung remah roti, bila disimpan pada suhu berbeda $\left(-20^{\circ} \mathrm{C}, 4^{\circ} \mathrm{C}\right.$, atau $\left.20^{\circ} \mathrm{C}\right)$ selama 7 hari menunjukkan kadar RS mencapai maksimum antara 2 dan 4 hari pada semua suhu penyimpanan, setelah kadar RS menurun. Kadar RS terendah ditemukan dalam roti jagung utuh setelah penyimpanan pada $-20^{\circ} \mathrm{C}(2,18 \mathrm{~g} / 100 \mathrm{~g})$ selama 7 hari. Studi tentang pengaruh penyimpanan dingin pada kecernaan pati tortilla in vitro menunjukkan penurunan kadar pati yang dapat dicerna dalam tortilla setelah 48 jam penyimpanan dingin, karena peningkatan jumlah RS. Perubahan ini terutama karena retrogradasi, yang ditunjukkan oleh peningkatan retrograded resistant starch (RRS) yang merupakan komponen terbesar kadar RS total [12]. 


\section{PEMBUATAN RS}

RS dapat dibuat dengan modifikasi pati dengan perlakuan fisik (perlakuan panas), perlakuan kimia, perlakuan enzimatis dan kombinasi panas dan enzimatis (Sajilata, Singhal and Kulkarni, 2006; Zhou et al., 2014).

\section{(i) Perlakuan Panas}

Perlakuan panas untuk pembentukan RS dapat diperoleh dengan memasak pati diatas suhu gelatinisasi yang dilanjutkan dengan pengeringan. Hasil RS yang bagus diperoleh dengan gelatinisasi pati pada suhu $120^{\circ} \mathrm{C}$ selama 20 menit, dilanjutkan dengan pendinginan pada suhu kamar, kemudian gel pati dibekukan selama satu malam pada suhu $-20^{\circ} \mathrm{C}$ dan dikeringkan pada suhu $60^{\circ} \mathrm{C}$ sebelum digiling. Beberapa kombinasi suhu dan waktu telah digunakan untuk membuat RS3 dari beberapa sumber pati. Pati dengan kadar amilosa normal, untuk meningkatkan hasil RS3 dilakukan dengan pemasakan suhu diatas $100^{\circ} \mathrm{C}$ (Sajilata, Singhal and Kulkarni, 2006).

Perlakuan hidrotermal, yaitu Heat moisture treatment (HMT) dan pendinginan merupakan modifikasi fisik yang dapat mengubah sifat-sifat fisikokimia pati tanpa merusak struktur granulanya. HMT adalah modifikasi secara fisik yang dilakukan pada kadar air yang terbatas (10-30\%) dan dipanaskan pada suhu tinggi $\left(20120{ }^{\circ} \mathrm{C}\right.$ ) selama 15 menit sampai 16 jam. Perubahan struktur dan sifatsifat fungsional pati bervariasi tergantung pada sumber pati dan kadar amilosa (Zavareze and Dias, 2011). HMT mendorong interaksi rantai polimer dengan memecah struktur kristalin dan memisahkan struktur heliks ganda di wilayah amorf, diikuti dengan penataan ulang kristalin yang pecah (Zavareze and Dias, 2011).

\section{(ii) Perlakuan Enzimatis}

Pati alami dihidrolisis menggunakan enzim a-amilase yang tahan panas, pululanase atau kombinasi keduanya. Penggunaan enzim pululanase menghasilkan produk RS yang mempunyai kualitas yang sama dengan pati atau tepung alami ketika dimasak tetapi mempunyai kandungan RS yang lebih tinggi dari pada penggunaan $\alpha$-amilase (Sajilata, Singhal and Kulkarni, 2006). Enzim a-amilase adalah endo-enzim yang memecah ikatan $\alpha-(1-4)-D-$ glukosida dalam pati., sedang enzim pululanase adalah endo-enzim yang memecah ikatan $\alpha-(1-6)$ seperti dapat dilihat pada Gambar 3.

RS yang dibuat dengan hidrolisis pati jagung dengan pululanase, dengan kondisi optimum untuk hidrolisis adalah suhu $46^{\circ} \mathrm{C}, \mathrm{pH} 5, \mathrm{o}$, waktu reaksi 24 jam dan pululanase 12 ASPU/g. hasil hidrolisis selanjutnya dimasak dalam autoklaf pada suhu $121^{\circ} \mathrm{C}$ selama satu jam, didinginkan pada suhu kamar dan kemudian disimpan pada suhu $4^{\circ} \mathrm{C}$ selama satu malam.

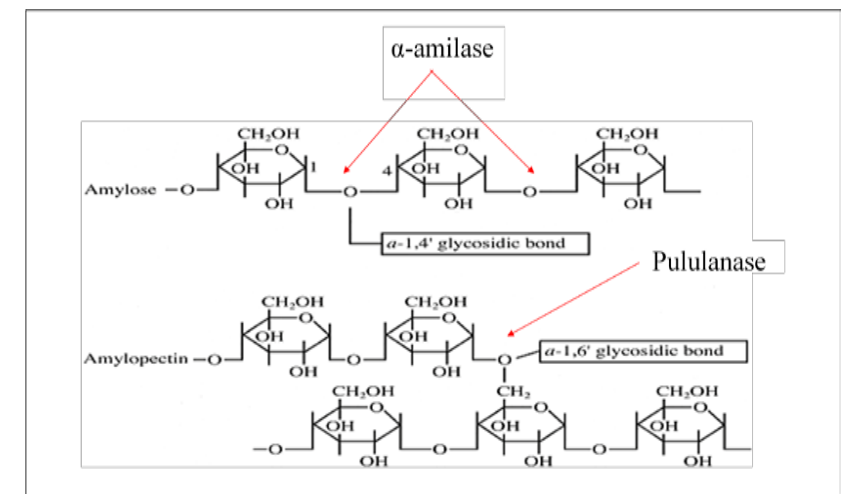

Gambar 3. Hidrolisis ikatan $\alpha$-(1-4) oleh a-amilase dan ikatan $\alpha-(1-6)$ oleh pululanase

\section{(iii) Perlakuan Panas Dan Enzim}

Metode ini merupakan kombinasi antara perlakuan panas dengan enzim, dilakukan dengan membuat pati retrogradasi yang dilanjutkan dengan hidrolisis kimia atau enzimatis untuk mengurangi atau menghilangkan bagian amorfous dari pati retrogradasi. RS dapat dibuat dengan gelatinisasi pati amilosa tinggi kemudian dilakukan pemutusan ikatan cabang dengan enzim pululanase dan selanjutnya produk yang dihasilkan dikeringkan atau diekstrusi (Sajilata, Singhal and Kulkarni, 2006).

Perlakuan pemasakan dan pendinginan diulang sebanyak dua kali, dan selanjutnya dikeringkan dan digiling. Metode ini akan menghasilkan pati dengan kadar RS sebesar 16,55\% (Zhang and Jin, 2011b). Peningkatan kadar RS dalam pati jagung menurut (Zhang and Jin, 2011a) dapat dilakukan dengan penambahan enzim $\alpha$-amilase yang termostabil sebelum perlakuan dengan enzim pulalanase. Kondisi optimum untuk a-amilase dalam produksi RS adalah suhu $90^{\circ} \mathrm{C}, \mathrm{pH} 5.5$, waktu reaksi 15 menit dan jumlah $\alpha$-amilase $4 \mu / \mathrm{g}$ dengan hasil RS yang diperoleh 58,87\% (w/w). Kondisi optimum (suhu, pH, waktu reaksi dan jumlah enzim) untuk aktivitas $\alpha$-amilase dan pulanase dalam pembentukan RS dapat dilihat pada Gambar 4. (iv) Pembuatan RS Pati Beras Indica Dengan Metode Enzimatis dan Fisik

Dalam pembuatan RS pati beras Indica ada dua tahap yang harus dilakukan, yaitu pembuatan/ isolasi pati beras Indica (Zavareze et al., 2010) dan pembuatan RS pati beras Indica (Zhou et al., 2014).

\section{(a) Pembuatan pati beras indica}

Menurut (Zavareze et al., 2010) isolasi pati beras dilakukan dengan metode Wang dan Wang (2004). Tepung beras direndam dalam larutan $\mathrm{NaOH}$ o,1\% dengan rasio $1: 2$ (w/v) selama 18 jam. Selanjutnya diaduk dan disaring dengan ayakan 63 $\mu \mathrm{m}$ dan disentrifus pada $1200 \mathrm{~g}$ selama 5 menit. Lapisan paling atas dihilangkan dan lapisan pati dibawahnya di re-slurried. Lapisan pati kemudian dicuci dua kali menggunakan larutan $\mathrm{NaOH} 0,1 \%$ dan disentrifus. Lapisan pati dicuci dengan air distilassi dan disentrifus. Pati kemudian di re- slurried dan dinetralkan dengan larutan $\mathrm{HCl}$ 1,0 M sampai $\mathrm{pH}$ 6,5 dan disentrifus. Pati netral dicuci tiga kali dengan air 
distilasi dan dikeringkan pada suhu $40^{\circ} \mathrm{C}$ sampai kadar air $11 \%$.

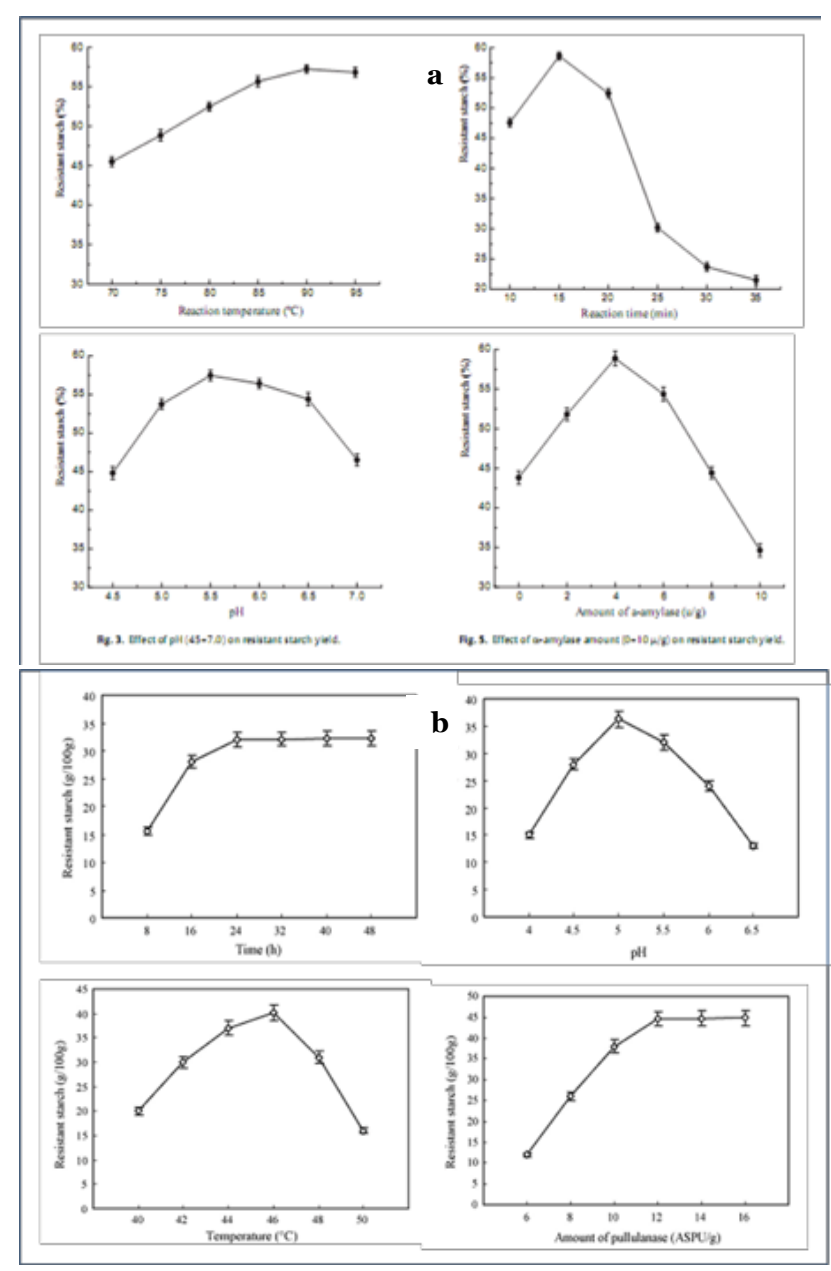

Gambar 4. Kondisi optimum pululanase (a) dan $\alpha$ milase (b) Sumber : (Zhang and Jin, 2011b, 2011a)

\section{Pembuatan RS Pati Beras Indica Secara Enzimatis Dan Fisik}

Pembuatan RS menurut penelitian (Zhou et al., 2014) dengan modifikasi pati secara enzimatik dan secara fisik. Pada modifikasi secara enzimatis dilakukan dengan dua cara, yaitu perlakuan modifikasi ganda mengunakan dua macam enzim, dan perlakuan modifikasi tunggal menggunakan satu macam enzim. Sedang modifikasi secara fisik dilakukan dengan perlakuan panas lembab.

\section{Perlakuan modifikasi ganda (dual modification-treated/ DMT)}

Pati beras Indica (10 g, 25\%w/v) digelatinisasi dengan air distilasi selama 30 menit pada suhu $80^{\circ} \mathrm{C}$ dan $\mathrm{pH}$ 6,o. Pati diperlakukan dengan $\alpha$-amilase pada $\mathrm{pH} 5,5$, suhu $80^{\circ} \mathrm{C}$ dengan waktu reaksi 40 menit dan dengan level $\alpha$-amilase $6 \mu / g$. Kemudian pululalnase ditambahkan sebanyak $4 \mu / \mathrm{g}$ pada $\mathrm{pH} 4,5$ dan suhu $46^{\circ} \mathrm{C}$ selama 12 jam. Campuran kemudian didinginkan sampai suhu kamar dan selanjutnya disimpan dalam refrigerator pada suhu $4^{\circ} \mathrm{C}$ selama satu malam. Pati disuspensikan dalam etanol absolut dan digojog selama 15 menit. Etanol dipisahkan dengan sentrifugasi (800o rpm, 15 menit, $4^{\circ} \mathrm{C}$ ) dan prosedur ini diulang sebanyak dua kali. Residu dicuci dua kali menggunakan air distilasi. Setelah pati dicuci kemudian diperlakukan dalam water bath mendidih selama 90 menit. Pati yang diperoleh dikeringkan pada suhu $60^{\circ} \mathrm{C}$ selama 24 jam, kemudian digiling dan diayak dengan ayakan 200 mesh untuk selanjutnya dilakukan analisis.

\section{(b) Perlakuan modifikasi tunggal (single modification-treated/SMT)}

Pembuatan pati modifikasi dengan SMT caranya sama dengan pati DMT, tetapi tanpa perlakuan enzim $\alpha$-amilase.

\section{(c) Perlakuan modifikasi panas lembab (heat- moisture-treated/ HMT)}

Pembuatan pati modifikasi dengan HMT dilakukan tanpa menggunakan enzim. Pati beras Indica $(10 \mathrm{~g}, 25 \% \mathrm{w} / \mathrm{v})$ digelatinisasi dengan air distilasi, diaduk selama 30 menit pada suhu $80^{\circ} \mathrm{C}$ dan $\mathrm{pH}$ 6,0. Setelah gelatinisasi, pati beras Indica diperlakukan dalam water bath mendidih selama 90 menit, kemudian dikeringkan pada suhu $60^{\circ} \mathrm{C}$ selama 24 jam, kemudian digiling dan diayak dengan ayakan 200 mesh untuk selanjutnya dilakukan analisis.

\section{KARAKTERISTIK PATI BERAS INDICA HASIL MODIFIKASI}

\section{(i) Kadar RS dan kecepatan hidrolisis pati}

Perbandingan kadar RS dan kecepatan hidrolisis pati beras Indica hasil ketiga cara modifikasi dan pati alami dapat dilihat pada Tabel 4 (Zhou et al., 2014).

Tabel 4.

Kadar RS dan kecepatan hidrolisis pati (\%)

\begin{tabular}{|c|c|c|c|c|c|c|}
\hline & $\begin{array}{l}\text { Kadar } \\
\text { RS }\end{array}$ & 2 jam & $6 \mathrm{jam}$ & 12 jam & 24 jam & 36 jam \\
\hline $\begin{array}{l}\text { Pati } \\
\text { native }\end{array}$ & $\begin{array}{l}2,52^{\mathrm{a}} \pm 1 \\
647\end{array}$ & $\begin{array}{l}25,7^{\mathrm{a}} \\
\pm 0,907\end{array}$ & $\begin{array}{l}37,5^{\mathrm{a}} \\
\pm 1,23\end{array}$ & $\begin{array}{l}45,3^{\mathrm{a}} \\
\pm 1,74\end{array}$ & $\begin{array}{l}5,13^{\mathrm{a}} \\
\pm 1,07\end{array}$ & $\begin{array}{l}53,7^{\mathrm{a}} \\
\pm 0,958\end{array}$ \\
\hline $\begin{array}{l}\text { Pati } \\
\text { HMT }\end{array}$ & $\begin{array}{l}15,3 \\
\pm 1,256\end{array}$ & $\begin{array}{l}12,2 \pm 1, \\
54\end{array}$ & $\begin{array}{l}14,0 \pm 1, \\
78\end{array}$ & $\begin{array}{l}15,3 \pm 1 \\
79\end{array}$ & $\begin{array}{l}17,3 \pm 0 \\
770\end{array}$ & $\begin{array}{l}18,2 \pm 0 \\
, 615\end{array}$ \\
\hline $\begin{array}{l}\text { Pati } \\
\text { SMT }\end{array}$ & $\begin{array}{l}35,2^{\mathrm{a}} \\
\pm 1, \mathrm{O} 73\end{array}$ & $\begin{array}{l}6,55^{\mathrm{a}} \\
\pm 0,929\end{array}$ & $\begin{array}{l}7,12^{\mathrm{a}} \\
\pm 1,09\end{array}$ & $\begin{array}{l}7,55^{\mathrm{a}} \\
\pm 0,784\end{array}$ & $\begin{array}{l}8,02^{\mathrm{a}} \\
\pm 0,890\end{array}$ & $\begin{array}{l}8,02^{\mathrm{a}} \\
\pm 1,28\end{array}$ \\
\hline $\begin{array}{l}\text { Pati } \\
\text { DMT }\end{array}$ & $\begin{array}{l}47, \mathrm{O}^{\mathrm{a}} \\
\pm 1,232\end{array}$ & $\begin{array}{l}3,17^{\mathrm{a}} \\
\pm 1,02\end{array}$ & $\begin{array}{l}4,53^{\mathrm{a}} \\
\pm 0,938\end{array}$ & $\begin{array}{l}5,17^{\mathrm{a}} \\
\pm 0,603\end{array}$ & $\begin{array}{l}5,19^{\mathrm{a}} \\
\pm 1,24\end{array}$ & $\begin{array}{l}5,19^{\text {a }} \\
\pm 1,04\end{array}$ \\
\hline \multicolumn{7}{|c|}{ Kadar RS (\%) = kadar glukosa x 0,9/berat pati x 100\% } \\
\hline \multicolumn{7}{|c|}{ Kecepatan pati hidrolisis $(5)=$ kadar gula reduksi $\times 0,9 /$ berat pati $\times 100 \%$} \\
\hline
\end{tabular}

Dari Tabel diketahui bahwa kadar RS pati DMT lebih tinggi dari pada pati alami, SMT dan HMT, yaitu sebesar 47,0\%. Semakin lama waktu hidrolisis enzimatik, kecepatan hidrolisis meningkat. Kecepatan hidrolisis pati DMT lebih rendah dari kedua cara modifikasi lainnya, karena setelah perlakuan enzim ganda ( $\alpha$-amilase dan pululanase), molekul pati terhidrolisa menjadi rantai pendek dan lurus. Rantai ini saling berikatan dengan ikatan hidrogen menjadi struktur heliks ganda yang rapat, sehingga terbentuk struktur kristalin baru dan mengurangi sisi pengikatan molekul pati dengan enzim yang membuat 
enzim sulit mendegradasi (Zhou et al., 2014). Menurut (Lehmann and Robin, 2007) pemutusan rantai cabang ikatan $\alpha-(1-6)$ menghasilkan rantai amilosa pendek yang dapat membentuk agregasi heliks ganda dan membentuk kritalin selama pendinginan resisten terhadap pencernaan. Sebaliknya rantai amilosa panjang mencegah pembentukan agregat dan membentuk cross-link selama pendinginan menghasilkan bahan tingkat kecernaannya lebih tinggi; Ilustrasi hidrolisis rantai pati oleh enzim $\alpha$-amilase dan pululanase dan pembentukan heliks ganda dilihat pada Gambar $5 \mathrm{~A}$.

Menurut [12] gelatinisasi pati beramilosa tinggi atau linierisasi amilopektin dengan enzim debranching (pululanase) yang dilanjutkan dengan retrogradasi yang terkendali digunakan secara luas untuk membuat RS. Beberapa peneliti juga melaporkan bahwa pati yang diberi perlakuan hidrotermal dan enzimatis dapat mendorong pembentukan SDS (Slowly Digestible Starch) [31]. Ilustrasi retrogradasi pati setelah dihidrolisis dengan enzim pululananse dapat dilihat pada Gambar $5^{\mathrm{B}}$.

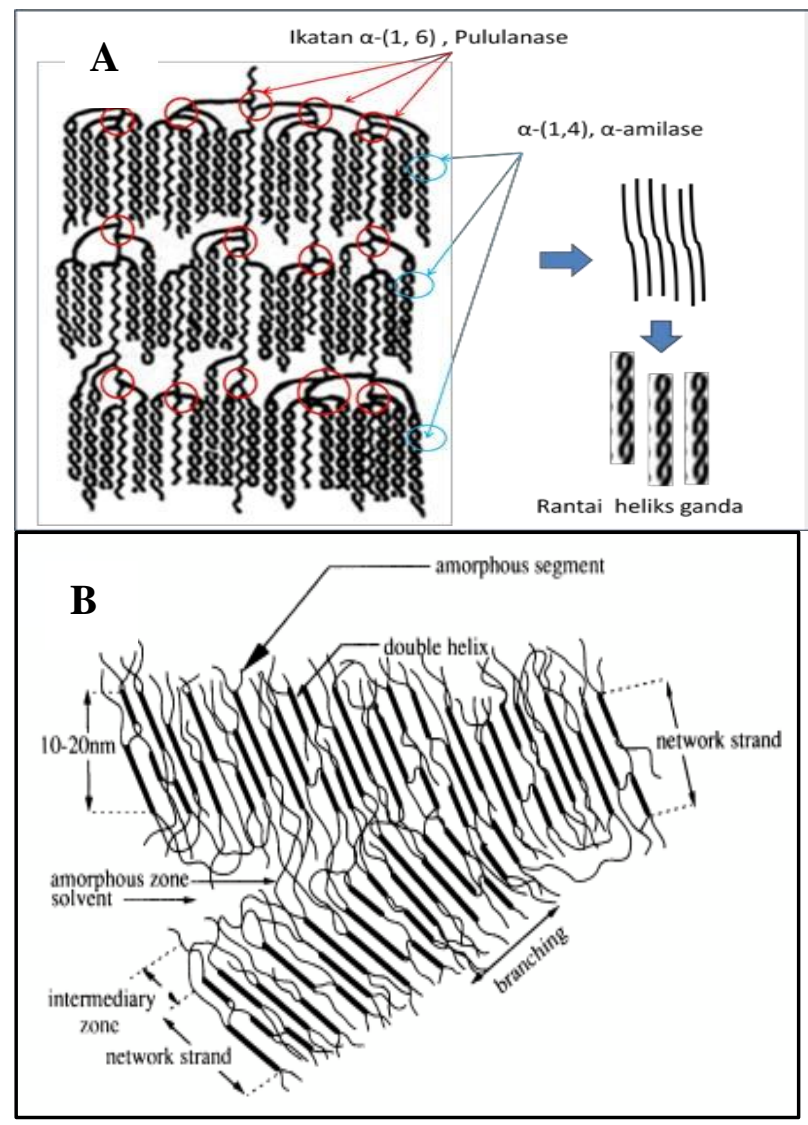

Gambar 5. (A) Hidrolisis pati dengan enzim enzim $\alpha-$ amilase dan pululanase dan pembentukan rantai heliks ganda baru; (B) Struktur gel amilosa hasil rekristalisasi sumber : (Lehmann and Robin, 2007)

Penurunan kecepatan hidolisis RS dalam pengujian kecernaan pati secara in vitro karena adanya amilosa yang lebih pendek dapat menurunkan kemampuan pati untuk dicerna oleh enzim (Zhou et al., 2014). Dengan demikian pati hasil DMT sangat resisten terhadap enzim.

Menurut (Zhang and Jin, 2011a) satu faktor penting dalam pembentukan RS adalah peningkatan rasio amilosa/amilopektin, karena rantai amilosa membentuk heliks ganda yang mereorganisasi struktur pati. Kemungkinan lain karena pengurangan panjang rantai amilosa menjadi mobil sehingga meningkatkan pembentukan kristal. Peningkatan densitas struktur kristal meningkatkan resistensi pati terhadap enzim.

(ii) Scanning electron micrographs (SEM) pati SEM granula pati alami dan pati modifikasi dapat dilihat pada Gambar 6. Granula pati beras Indica nativ memiliki permukaan yang halus dan bentuknya poligonal tidak beraturan dan tidak ditemukan adanya keretakan meskipun setelah modifikasi dengan metode yang berbeda, bentuk granula berubah. Permukaan granula pati HMT terlihat tidak beraturan, kasar, morfologi tidak seragam dan strukturnya relative longgar. Permukaan granula pati SMT nampak mempunyai partikel besar dan struktur tiga dimensi dengan permukaanya halus. Dibandingkan dengan granula pati DMT terlihat padat, kompak dan struktur seperti lembaran yang kurang halus dari pada pati alami, tetapi granula pati DMT masih mempertahankan struktur partikelnya relatif lengkap. Struktur ini menunjukkan rekristalisasi pati tergelatinisasi, molekul amilosa dan amilopektin mengalami pengaturan ulang melalui ikatan hidrogen dan bergerak lebih dekat satu sama yang lain. Hal ini menyebabkan re-komposisi campuran kristal dan integritas pati dapat dipertahankan dan derajat kristalinitas pati resisten meningkat, sehingga aktivitas enzimatik menurun dan meningkatkan ketahanan pati untuk dicerna (Zhou et al., 2014).
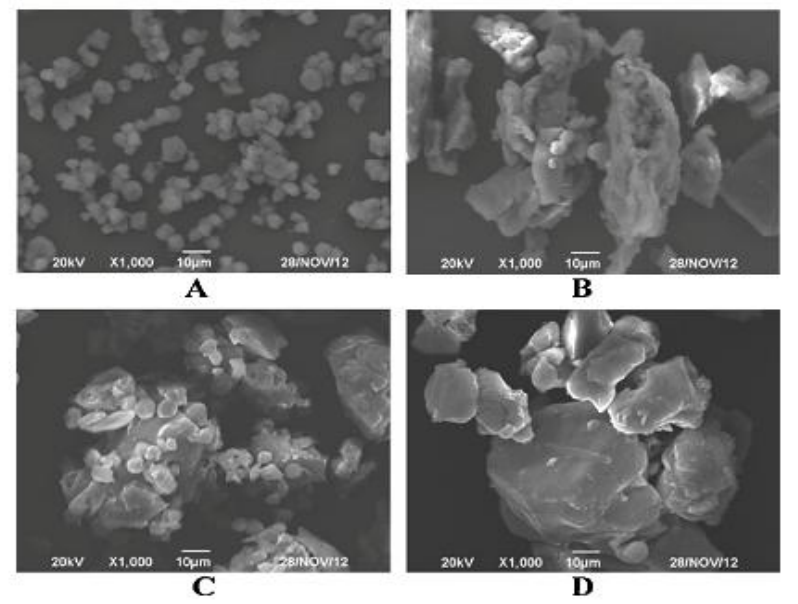

Gambar 6. SEM pati alami dan pati modifikasi : (A) pati alami, (B) pati HMT, (C) pati SMT dan (D) pati DMT Sumber : (Zhou et al., 2014) 


\section{Pola difraksi sinar-X dan kristalinitas relatif pati}

Pola difraksi sinar $\mathrm{X}$ pati yang telah mengalami perlakuan modifikasi dapat dilihat pada Gambar 7. Ada tiga tipe struktur kristal yang berbeda, yaitu kristalinitas pati tipe $\mathrm{A}$, tipe $\mathrm{B}$ dan tipe $\mathrm{V}$. Kristalinitas pati tipe A terutama terdapat pati sereal, seperti pati jagung, gandum dan beras, dengan refleksi kuat pada $15^{\circ}, 17^{\circ}, 18^{\circ}$ dan $23^{\circ}$. Kristalinitas pati tipe B terutama terdapat pati singkong, buah-buahan seperti kentang dan pisang, dengan refleksi kuat pada $5,6^{\circ}, 17^{\circ}, 22^{\circ}$ dan $24^{\circ}$. Kristalinitas tipe $\mathrm{V}$ umumnya berhubungan dengan komplek amilosa-lipida dengan refleksi pada $14,5^{\circ}$ dan $19,5^{\circ}$. Pati beras Indica alami menunjukkan tipe pola dengan refleksi kuat pada $2 \partial=15.2$, 17.0, 18.0 dan 23.1. Pola difraksi sinar X pati HMT karakternya tipe $\mathrm{B}$ dan tipe $\mathrm{V}$ dengan puncak difraksi pada $2 \partial=7$ ${ }^{\circ}, 12^{\circ}, 19^{\circ}$ dan $22^{\circ}$. Perlakuan hidrotermal mengubah pola dari A menjadi B juga telah dilaporkan sebelumnya (Zhou et al., 2014).

Beberapa peneliti telah melaporkan kenaikan intensitas difraksi sinar-X pada pati jagung dan ubi jalar, yang disebabkan karena pergerakan rantai heliks ganda dalam kristal pati yang menghasilkan matriks kristal yang lebih teratur dari pada pati nativ. Meskipun telah diidentifikasi adanya penurunan kritalinitas relatif pada kentang. Penurunan intensitas sinar X dikarenakan perlakuan hidrotermal juga mengurangi kritalinitas dan menaikkan bagian amorfous pada lamela semi kristalin (Zavareze and Dias, 2011).

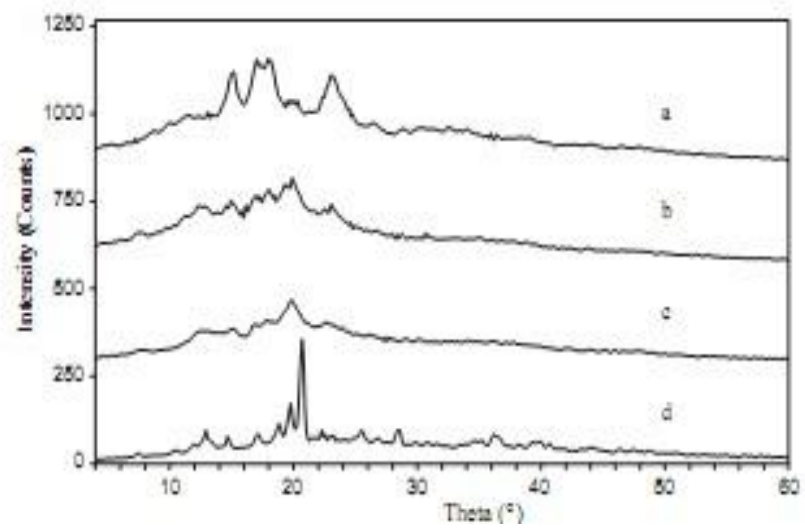

Gambar 7. Pola difraksi sinar-X : (a) pati alami, (b) pati HMT, (c) Pati SMT dan (d) pati DMT Sumber : (Zhou et al., 2014)

Pola difraksi untuk pati SMT berubah dari tipe A menjadi kombinasi tipe A dan tipe $\mathrm{V}$ (refleksi pada $2 \partial=8,03^{\circ}, 12,6^{\circ}, 15,1^{\circ}$ dan $\left.19,9^{\circ}\right)$. Difraksi sinar $\mathrm{X}$ pati DMT dan HMT menunjukkan hilangnya intensitas refleksi pada $2 \partial=15^{\circ}, 18^{\circ}$ dan $23^{\circ}$ dan penguatan intensitas refleksi pada $2 \partial=7^{\circ}, 12^{\circ}, 14^{\circ}, 19^{\circ}$, $20^{\circ}$ dan $22^{\circ}$, hal ini menunjukkan penurunan bentuk kristalin tipe A dan peningkatan bentuk kritalin tipe B dan tipe V(Zhou et al., 2014).

Kristalinitas pati alami, HMT, SMT dan DMT berdasarkan difraksi sinar-X adalah 18,1\%, 20,2\%, 27,0\% dan 51,0\%. Dibandingkan dengan pati nativ, kristalinitas pati HMT dan SMT turun tetapi pati DMT meningkat.

Menurut (Zavareze and Dias, 2011) derajat kristalinitas dapat menggambarkan ukuran kristal, jumlah bagian kristalin yang dipengaruhi oleh panjang rantai amilopektin, orientasi heliks ganda dalam kristalin dan tingkat interaksi antara heliks ganda. Jika metode modifikasi ganda digunakan untuk pembuatan RS, dua enzim ( $\alpha$-amilase dan pululanase) menghidrolisa rantai pati menjadi rantai lurus panjang. Rantai lurus ini kemudian membentuk heliks pada proses selanjutnya. Proses heat-moisture menyebabkan struktur menjadi lebih rapat dan meningkatkan kristalinitas $\mathrm{RS}$, sehingga resistensi terhadap amilolisis menjadi lebih besar (Zhou et al., 2014).

\section{Analisis karakteristik thermal dan thermogravimetri pati}

Parameter termal dan termogravimetri pati nativ, HMT, SMT dan DMT dianalisa menggunakan DSC-TGA dan hasilnya disajikan pada Tabel 5. Dari Tabel 5 diketahui terjadi peningkatan suhu To, Tp, Tc, $\Delta \mathrm{H}$ yang signifikan pada semua perlakuan bila dibandingkan dengan pati nativ dan peningkatan yang paling besar terjadi pada pati DMT. Peningkatan To-Tp menunjukkan perubahan internal yang berbeda pada perlakuan yang berbeda yang menyebabkan terjadinya pembentukan kristalitas dan jumlah heliks ganda dengan kestabilan yang berbeda. Peningkatan $\Delta \mathrm{H}$ (energi yang diperlukan untuk proses penghancuran kristal pati) menunjukkan bahwa jumlah heliks ganda pati DMT lebih besar atau interaksi antar rantai pati pada daerah kristalin lebih kuat. Pada suhu $214^{\circ} \mathrm{C}$ pati nativ memiliki puncak eksotermik yang besar yang menunjukkan dekomposisi pati yang besar sehingga kehilangan berat sampai 78,8\%. HMT, SMT dan DMT mempunyai puncak eksotermik yang lebih tinggi dibandingkan pati nativ dan kehilangan berat yang lebih rendah.

Tabel5.

Karakteristik thermal dan thermogravimetri pati

\begin{tabular}{|c|c|c|c|c|c|c|}
\hline & $\mathrm{T}_{\mathrm{o}}\left({ }^{\circ} \mathrm{C}\right)$ & $\mathrm{T}_{\mathrm{p}}\left({ }^{\circ} \mathrm{C}\right)$ & $\mathrm{T}_{\mathrm{c}}\left({ }^{\circ} \mathrm{C}\right)$ & $\begin{array}{l}\Delta \mathrm{H} \\
(\mathrm{J} / \mathrm{g})\end{array}$ & $\begin{array}{l}\text { Phase } \\
\text { transition } \\
\text { temperatu } \\
\text { re }\left({ }^{\circ} \mathrm{C}\right) \\
\end{array}$ & TG(\%) \\
\hline Pati & $133^{\mathrm{a}} \pm 1$ & $158^{a}$ & $194^{\mathrm{a}}$ & $37,1^{\mathrm{a}}$ & $214^{\mathrm{a}}$ & $72,8^{a}$ \\
\hline native & 06 & $\pm 1,06$ & $\pm 1,41$ & $\pm 1,70$ & $\pm 1,714$ & $\pm 1,10$ \\
\hline Pati & 201 & $205 \pm 1$ & $214 \pm 1,8$ & $42,3 \pm$ & $255 \pm 1,40$ & $50,1 \pm 0$ \\
\hline HMT & $\pm 1,35$ & 43 & 5 & 1,45 & & 914 \\
\hline Pati & $203^{b}$ & $223^{b}$ & $232^{\mathrm{a}}$ & $51,3^{a}$ & 267 & $45,7^{b}$ \\
\hline SMT & $\pm 1,40$ & $\pm 1,28$ & $\pm 1,03$ & $\begin{array}{l} \pm 0,82 \\
1\end{array}$ & $\pm 0,811$ & $\pm 1,43$ \\
\hline Pati & 207 & 226 & $235^{\mathrm{a}}$ & $58,7^{\mathrm{a}}$ & $295 \pm 1,23$ & $36,4^{\mathrm{a}}$ \\
\hline DMT & $\pm 1,01$ & $\pm 1,72$ & $\pm 1,41$ & $\pm 1,41$ & & $\pm 1,26$ \\
\hline $\begin{array}{l}\text { Masing- } \\
\text { a mengir } \\
\text { b mengi }\end{array}$ & $\begin{array}{l}\text { hasing } \mathrm{n} \\
\text { likasikar } \\
\text { dikasika }\end{array}$ & $\begin{array}{l}\text { enunj } \\
\text {,01 } \\
\text {,05 di }\end{array}$ & n nilai & $\mathrm{ta} \pm \mathrm{st}$ & $\begin{array}{l}\mathrm{r} \text { deviasi ( } \\
\text { MT }\end{array}$ & 10) \\
\hline
\end{tabular}

Sumber : (Zhou et al., 2014)

TGA secara luas digunakan untuk mengevaluasi hubungan antara kehilangan berat dan suhu pati. Dibandingkan dengan tiga pati lainnya, pati DMT kehilangan berat lebih sedikit, yang menunjukkan tipe kristal yang berbeda. Penelitian sebelumnya juga 
menunjukkan bahwa metode TGA ditemukan bahwa ada perbedaan terhadap ketahanan panas antara amilosa dan amilopektin dalam pati jagung. Hasil ini menunjukkan bahwa pati DMT dapat digunakan untuk mempertahankan struktur kristal dibawah suhu $207^{\circ} \mathrm{C}$ dan mempunyai stabilitas panas lebih baik dari pada pati yang lain (Zhou et al., 2014).

\section{APLIKASI RS}

Aplikasi RS dalam produk-produk makanan dapat digunakan sebagai food ingredient dan food additive. Menurut (Fuentes-Zaragoza, M.J. RiquelmeNavarrete, et al., 2010) digunakan untuk pengembangan produk karena dua hal, yaitu karena potensi fisiologis yang menguntungkan dan sifat-sifat fungsional unik, yang menghasilkan produk dengan kualitas tinggi yang tidak bisa dicapai oleh serat larut tradisional. Penambahan RS dalam produk yang dipanggang, produk pasta dan minuman menghasilkan sifat tekstur lebih baik dan bermanfaat untuk kesehatan (Yue and Waring, 1998; Baixauli et al., 2008; Millati et al., 2019).

Aplikasi RS dalam industri terutama untuk produk makanan dengan kadar air rendah. Produkproduk seperti roti, muffin, dan sereal sarapan dapat dibuat dengan menggunakan RS sebagai sumber serat. Jumlah RS yang digunakan untuk menggantikan tepung tergantung pada pati tertentu yang sedang digunakan, aplikasi tingkat serat yang diinginkan, dan dalam beberapa kasus, strukturfungsi yang diinginkan. $\mathrm{RS}_{3}$ dengan titik leleh minimal $140^{\circ} \mathrm{C}$, dapat digunakan sebagai pengganti tepung rendah kalori untuk produk roti dengan karakteristik yang dihasilkan adalah masak merata, warna coklat keemasan, aroma yang menyenangkan, permukaan merekah. Kue spons yang kualitas sangat baik dapat dibuat dengan mengganti 30\% dari tepung dengan $\mathrm{RS}_{3}$ pati jagung, RS 4 (dibuat dengan cross-linked pati jagung dan kombinasi pendinginan dan crosslinked $\mathrm{RS}_{4}$ pati jagung) sedangkan untuk cake lapis kuning sebesar 12,5\%. Pati jagung amilosa tinggi dengan RS di 20\%-24\% menunjukkan sifat yang sangat baik sebagai pelapis tablet (Po, Czuchajowska and Pomeranz, 1994; Haynes et al., 2000; Myung-Hee-Kim, Jeong-Ok-Kim, and Mal-Shick Shin, 2001; Dimantov et al., 2004; Nurhayati, 2019).

\section{SIMPULAN}

1. Hidrolisis pati beras dengan enzim ganda $\alpha$-amilase dan pululanase (DMT) dapat meningkatkan kadar RS tertinggi $(51,0 \%)$ karena meningkatnya derajat kristalinitas pati.

2. RS yang tinggi mengakibatkan peningkatan suhu gelatinisasi, $\Delta \mathrm{H}$ dan suhu fase transisi dan penurunan kecepatan hidrolisis pati dan kehilangan berat.
3. RS mempunyai sifat fungsional dan efek fisologis terhadap kesehatan yang menguntungkan.

4. RS dapat diaplikasikan sebagai food ingredient dan food additive dalam berbagai produk makanan dan minuman.

\section{DAFTAR RUJUKAN}

Abd-Elmoneim-O-Elkhalifa, Schiffler, B. and Bernhard, R. (2004) 'Effect of fermentation on the starch digestibility, resistant starch and some physicochemical properties of sorghum flour', Nahrung/Food, 48(2), pp. 91-94.

Adamu, B. O. A. (2001) 'Resistant starch derived from extruded corn starch and guar gum as affected by acid and surfactants: Structural characterization', Starch/Staerke, 53(11), pp. 582-591. doi: 10.1002/1521379X(200111)53:11<582::AID-STAR582>3.0.CO;2-G.

Baixauli, R. et al. (2008) 'Distinctive sensory features introduced by resistant starch in baked products', $L W T$ Food Science and Technology, 41(10), pp. 1927-1933. doi: 10.1016/j.lwt.2008.01.012.

Berry, C. S. (1986) 'Resistant starch: Formation and measurement of starch that survives exhaustive digestion with amylolytic enzymes during the determination of dietary fibre', Journal of Cereal Science. Academic Press Inc. (London) Limited, 4(4), pp. 301314. doi: 10.1016/So733-5210(86)80034-o.

Dimantov, A. et al. (2004) 'Study of high amylose corn starch as food grade enteric coating in a microcapsule model system', Innovative Food Science and Emerging Technologies, 5(1), pp. 93-100. doi: 10.1016/j.ifset.2003.11.003.

Faraj, A., Vasanthan, T. and Hoover, R. (2004) 'The effect of extrusion cooking on resistant starch formation in waxy and regular barley flours', Food Research International, 37(5), pp. 517-525. doi: 10.1016/j.foodres.2003.09.015.

Fuentes-Zaragoza, E., Riquelme-Navarrete, M. J., et al. (2010) 'Resistant starch as functional ingredient: A review', Food Research International. doi: 10.1016/j.foodres.2010.02.004.

Fuentes-Zaragoza, E., Riquelme-Navarrete, M.J., et al. (2010) 'Resistant starch as functional ingredient: A review', Food Research International, 43(4), pp. 931942. doi: 10.1016/j.foodres.2010.02.004.

Fuentes- Zaragoza, E. et al. (2011) 'Resistant starch as prebiotic: A review', Starch - Stärke, 63(7), pp. 406-415. doi: 10.1002/star.201000099.

Haynes, L. et al. (2000) 'Process for making enzymeresistant starch for reduced-calorie flour replacer. Wilmington, Del.: Nabisco Technology Co. 2000.', U.S. patent 6,013,299.

Holm J, Asp NG, Bjorck I (no date) 'Factors affecting enzymatic degradation of cereal starches in vitro and in vivo"', in Cereal in a European context.

Kavita, V. et al. (1998) Effects of processing, storage time and temperature on the resistant starch of foods, undefined. 
Lehmann, U. and Robin, F. (2007) 'Slowly digestible starch - its structure and health implications: a review', Trends in Food Science and Technology, 18(7), pp. 346355. doi: 10.1016/j.tifs.2007.02.009.

Liljeberg, H., Åkerberg, A. and Björck, I. (1996) 'Resistant starch formation in bread as influenced by choice of ingredients or baking conditions', Food Chemistry, 56(4), pp. 389-394. doi: 10.1016/03088146(95)00199-9.

'Los alimentos del bienestar la alimentación del siglo XXI - IAlimentos' (no date).

Mikulíková, D., Masár, Š. and Kraic, J. (2008) 'Biodiversity of Legume Health-promoting Starch', Starch - Stärke, 60(8), pp. 426-432. doi: 10.1002/star.200700693.

Millati, T. et al. (2019) 'Physicochemical Properties, In vitro Starch Digestibility and Estimated Glycemic Index Following the Accelerated Aging of Freshly Harvested Rice', Pakistan Journal of Nutrition, 18(4), pp. 346-353. doi: 10.3923/pjn.2019.346.353.

Myung-Hee-Kim, Jeong-Ok-Kim, and Mal-Shick Shin (2001) 'Effects of resistant starches on the characteristics of sponge cakes', J Korean Soc Food Sci Nutr, 30(4), pp. 623-629.

Nugent, A. P. (2005) 'Health properties of resistant starch', Nutrition Bulletin, 30(1), pp. 27-54. doi: 10.1111/j.1467-3010.2005.00481.x.

Nurhayati, N. (2019) 'MODIFIKASI PATI SECARA ASETILASI DAN APLIKASINYA PADA PEMBENTUKAN FILM', Jurnal Agrotek Ummat, 6(2), pp. 100-200.

Po, Y. ., Czuchajowska, Z. and Pomeranz, Y. (1994) 'Enzyme-resistant starch in yellow layer cake', Cereal Chem, 71(1), pp. 69-75.

Putseys, J. A., Lamberts, L. and Delcour, J. A. (2010) 'Amylose-inclusion complexes: Formation, identity and physico-chemical properties', Journal of Cereal Science, 51(3), pp. 238-247. doi: 10.1016/j.jcs.2010.01.011.

Ratnayake, W. S. and Jackson, D. S. (2008) 'Thermal Behavior of Resistant Starches RS 2, RS 3, and RS 4', Journal of Food Science, 73(5), pp. C356-C366. doi: 10.1111/j.1750-3841.2008.00754.x.

Ring, S. G. et al. (1988) 'Resistant starch: Its chemical form in foodstuffs and effect on digestibility in vitro', Food Chemistry, 28(2), pp. 97-109. doi: 10.1016/03088146(88)90139-2.

Sajilata, M. G., Singhal, R. S. and Kulkarni, P. R. (2006) 'Resistant Starch-A Review', Comprehensive Reviews in Food Science and Food Safety, 5(1), pp. 1-17. doi: 10.1111/j.1541-4337.2006.tboo076.x.

Sanz, T., Salvador, A. and Fiszman, S. M. (2008) 'Resistant starch (RS) in battered fried products: Functionality and high-fibre benefit', Food Hydrocolloids, 22(4), pp. 543-549. doi: 10.1016/j.foodhyd.2007.01.018.

Schweizer, T. F. et al. (1990) 'Nutrients excreted in ileostomy effluents after consumption of mixed diets with beans or potatoes. II. Starch, dietary fibre and sugars', European Journal of Clinical Nutrition, pp. $567-575$.

Sha, X. S. et al. (2012) 'Preparation and physical characteristics of resistant starch (type 4) in acetylated indica rice', Food Chemistry. Elsevier Ltd, 134(1), pp. 149-154. doi: 10.1016/j.foodchem.2012.02.081.

Sharma, A. and Yadav, B. S. (2008) 'Resistant starch: Physiological roles and food applications', Food Reviews International, 24(2), pp. 193-234. doi: 10.1080/87559120801926237.

Sievert, D. and Pomeranz, Y. (1989) Enzyme-Resistant Starch. I. Characterization and Evaluation by Enzymatic, Thermoanalytical, and Microscopic Methods.,

http://online.cerealsgrains.org/publications/cc/backis sues/1989/Documents/CC1989a106.html.

Topping, D. L., Fukushima, M. and Bird, A. R. (2003) 'Resistant starch as a prebiotic and synbiotic: state of the art', Proceedings of the Nutrition Society, 62(1), pp. 171176. doi: 10.1079/PNS2002224.

Waigh, T. A. et al. (1997) 'Analysis of the native structure of starch granules with X-ray microfocus diffraction', Macromolecules, 30(13), pp. 3813-3820. doi: 10.1021/ma970075w.

Wu, H. . and Sarko, A. (1978) 'The double helical molecular structure of crystalline Aamylose', Carbohydr Res, 61(7).

Xie, F. et al. (2013) 'Starch-based nano-biocomposites', Progress in Polymer Science. Elsevier Ltd, 38(10-11), pp. 1590-1628. doi: 10.1016/j.progpolymsci.2013.05.002.

Yue, P. (National S. and C. C. and Waring, S. (1998) 'Resistant starch in food applications', Cereal foods world (USA), 43(9), pp. 690-695.

Zavareze, E. D. R. and Dias, A. R. G. (2011) 'Impact of heat-moisture treatment and annealing in starches: A review', Carbohydrate Polymers. Elsevier Ltd., 83(2), pp. 317-328. doi: 10.1016/j.carbpol.2010.08.064.

Zavareze, E. da R. et al. (2010) 'Effect of heat-moisture treatment on rice starch of varying amylose content', Food Chemistry, 121(2), pp. 358-365. doi: 10.1016/j.foodchem.2009.12.036.

Zhang, H. and Jin, Z. (2011a) 'Preparation of products rich in resistant starch from maize starch by an enzymatic method', Carbohydrate Polymers. Elsevier Ltd., 86(4), pp. 1610-1614. doi: 10.1016/j.carbpol.2011.06.070.

Zhang, H. and Jin, Z. (2011b) 'Preparation of resistant starch by hydrolysis of maize starch with pullulanase', Carbohydrate Polymers, 83(2), pp. 865-867. doi: 10.1016/j.carbpol.2010.08.066.

Zhou, Y. et al. (2014) 'Structure characterization and hypoglycemic effects of dual modified resistant starch from indica rice starch', Carbohydrate Polymers. Elsevier Ltd., 103(1), pp. 81-86. doi: 10.1016/j.carbpol.2013.12.020. 